\title{
Communication Management of Islamic Sharia Agency in Applying Women's Islamic Fashion in Banda Aceh
}

\author{
Ade Irma $^{12}$, Mohd. Hatta ${ }^{3}$, Syukur Kholil ${ }^{3}$ \\ ${ }^{1}$ Ph.D Student in State IslamicUniversity of North Sumatera (UINSU) Medan, Indonesia \\ ${ }^{2}$ Lecturer in State Islamic University of Ar-Raniry, Banda Aceh, Indonesia \\ ${ }^{3}$ Lecturer in State IslamicUniversity of North Sumatera (UINSU) Medan, Indonesia \\ cutalma@dharmawangsa.ac.id
}

\begin{abstract}
The aim of the study is to find out the communication management of Islamic Sharia Agency in Applying Women's Islamic Fashion in Banda Aceh. The result shows that the most girls' appearance in Banda Aceh still does not apply the rules as socialized by the Islamic Sharia Agency. The mismatch between the applications in appearance with the rules for Islamic appearance is certainly not only seen as a single violation, but more understood as a whole reality, as a social reality of communication. The reality of life is very dynamic and constantly changing. Changes in the way students look must be balanced with the rules in force. Offsetting can be circumvented through communication
\end{abstract}

Keywords

Accounting information; organizational culture; decision

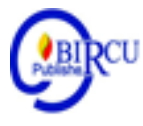

\section{Introduction}

A person's education both obtained from formal and non-formal institutions will contribute in appearance. Every individual tends to choose and wear clothes according to what they know, learn, and understand. In addition, mass media and social media today greatly affect the community, especially the younger generation in clothing. In accordance with the statement of Edy P. Irawady as Deputy for the Coordination of Trade Industry that the Indonesian Muslim community is now fashion literate and the launch of Indonesia as the center of world Muslim fashion in 2020 is not excessive. ${ }^{1}$ Mass media and social media offer many choices of modes that can be consumed by everyone in a very easy way. The ease of accessing the media enriches the style of diversity of appearance for Banda Aceh City women.

Communication management is one of the important aspects in implementing a program or policy. Whether an activity is reached or not depends on the management of communication carried out by an institution. This achievement dependence is caused by the institution that has communication management, of course, will carry out the process of managing messages intentionally, concretely, planned, and measured. Message management is carried out by the stages of planning, organizing, implementing, controlling, and evaluating the elements of communication. These stages of management will provide a clear, measurable picture of the program's journey and will also show where the strengths and weaknesses of the process are. And this stage process should also be carried out effectively and efficiently by Banda Aceh Islamic Sharia Agency in order to implement an Islamic appearance in Banda Aceh.

\footnotetext{
${ }^{1}$ Edy P. Irawady, "Potensi Kiblat Mode Muslim Dunia," dalam Warta Ekspor (April 2015), p. 6.
} 
Thus the importance of communication management to be carried out in Banda Aceh Islamic Sharia Agency in order to implement the Islamic appearance of Banda Aceh women, this research is important to do. Aceh Province Special Region Qanun Number 11 Year 2002 Article 13 and Article 23 have been established, socialized and carried out by the Aceh Regional Government. And for the smooth implementation of Qanun effective and efficient communication management is needed. Thus, proper, clear, and relevant communication management must certainly be carried out in Banda Aceh Islamic Sharia Agency so that the implementation of Islamic appearance can proceed as expected, and get a positive response from the community, especially in Tanah Rencong, Aceh.

\section{Review of Literature}

\subsection{Communication Management}

Communication is a form of human interaction that influences each other influences one another, intentionally or unintentionally. Not limited to forms of communication using verbal language, but also in terms of facial expression, painting, art and technology. Whereas Islam in language means submissive, obedient, and peaceful. Islam according to the term is the name of religion which Allah revealed to guide people to the right path and according to human nature. Islam is a religion of da'wah means religion which always encourages its followers to always actively carry out Da'wah activities. (Batubara, 2019)

Communication management is one of the solutions in addressing the phenomenon of student appearance that is not in accordance with Qanun perspective in the Banda Aceh State University. The application of policies requires appropriate management by paying attention to and considering aspects of the changes that occur in each individual in his life. These changes include changes in the environment, technological progress, and also changes in the way of looking at a problem and phenomenon. To obtain the right solution, this study uses references in the form of theories that are relevant to the problems raised.

Communication management consists of two different basic concepts. The two concepts are management and communication. The management concept is more about how to manage. While the concept of communication as a process of information transmission and the process of interaction of ideas. Although both concepts show differences because they originate from two different studies, these two concepts can be integrated into one specific study in communication studies. In the era of information globalization, the concept of communication management is increasingly being used, especially institutions that want to run programs. As Siagian revealed, this century is a century of management because everything requires management and knowledge. ${ }^{2}$ Therefore, communication management becomes important so that the institution's program of activities can be applied effectively and efficiently. Following is an explanation of these two concepts.

\subsection{Management Stages}

Management stages include planning, organizing, mobilizing, controlling, and evaluating. ${ }^{3}$ The following five stages of communication management should be carried out by individuals or institutions when running their programs.

\section{a. Communication planning}

Communication planning is a management function that includes the process of defining goals, establishing strategies to achieve those goals, and developing plans to

\footnotetext{
${ }^{2}$ Sondang P. Siagian, Manajemen Strategis (Yogyakarta: BPFE UGM, 1998), p. 2.

${ }^{3}$ Riswandi, Ilmu Komunikasi (Jakarta: Graha Ilmu, 2009), p. 147.
} 
integrate and coordinate activities. ${ }^{4}$ The slightest work done by someone begins with a plan or intention. The plan is sometimes implied in the heart or written in a neat, complete, and systematic program. Programming does not work well if it does not have a clear purpose. This shows that every planning that will be done, there is hope in it, and that hope becomes the motivation. To achieve expectations or goals, it requires guidelines (planning) that contain various programs that are organized and systematic. This is important so that people who carry it out are easier and have uniformity in working. ${ }^{5}$ Planning tends to be more action oriented. ${ }^{6}$

Three principles for preparing communication planning. First, communication planning requires consultation. Planning is a shared grip. Planning should be a reflection of shared aspirations. Planning compiled together will be carried out properly by all parties who compile it. Second, planning must be flexible. Planning is arranged not rigidly. Planning considers some anticipation of changes in the implementation of the plan. Plans made can still be implemented even with adjustments. Third, communication planning must be clear and concrete. The series of process activities is made clear and real, understandable, and does not cause multiple interpretations. Communication planning is intended to overcome obstacles to achieve effectiveness. While the usefulness of planning to implement the program to be achieved, whether for imaging and others. ${ }^{7}$

There are eight principles of communication planning; 1) significance, namely the level of meaningfulness that depends on the social interests of the proposed communication objectives; 2) feasibility, i.e. technical feasibility and cost estimation, 3) relevance, 4) definitiveness, namely the use of simulation techniques to carry out plans, 5) adaptability, i.e. dynamic and changeable planning, 6) time, namely the natural cycle of the subject of planning, the need to change situations that cannot be endured. 7) Monitoring, namely to ensure the plan works effectively, 8) subject matter, which is the subject that will be planned consisting of goals and objectives, programs, resources, budget, and social context. ${ }^{8}$

\section{b. Organizing}

Organizing is the preparation of organizational structure related to the objectives and in accordance with the resources owned without ignoring the surrounding environment. ${ }^{9}$ Organizing is done after finishing setting goals and planning carefully, steadily, neatly, carefully, and precisely. ${ }^{10}$ The organizing process includes activities or efforts in distributing tasks based on expertise by determining what tasks must be done, who should do it, how to do it, how to classify those tasks, who should report to whom, and where the decision should be made. ${ }^{11}$

\footnotetext{
${ }^{4}$ Alo Liliweri, Sosiologi dan Komunikasi Organisasi (Jakarta: Bumi Aksara, 2014), p. 471.

5 Jahril Bintang, "Fungsi Perencanaan dalam Pelaksanaan Dakwah," dalam Jakfar Puteh \& Saifullah (ed.), Dakwah Tekstual \& Kontekstual: Peran dan Fungsinya dalam Pemberdayaan Ekonomi Umat (Yogyakarta: Pustaka Pelajar, 2001), p. 49.

${ }^{6}$ John M. Bryson, Perencanaan Strategis bagi Organisasi Sosial, terj. M. Miftahuddin (Yogyakarta: Pustaka Pelajar, 2000), p. 8.

${ }^{7}$ Cangara, Perencanaan, p. 41.

${ }^{8}$ Ibid.

9 T. Hani Handoko, Manajemen (Yogyakarta: BPFE, 1993), h. 167. Lihat juga Said Aqil Husin Al-Munawar dan Tayar Yusuf, Etika Manajemen: Kepemimpinan Pemerintahan, Perniagaan dan Masyarakat (Jakarta: Ghalia Indonesia, 2002), p.11

${ }^{10}$ Alwahidi Ilyas, Manajemen Dakwah: Kajian Menurut Perspektif Al-Quran (Surakarta: LPKBN, 2014), p. 38.

${ }^{11}$ Liliweri, Sosiologi, p. 471.
} 


\section{c. Actuating}

Implementation is to move, dynamism, control all organizational resources in an effort to achieve goals, and motivate the implementers to enable them to achieve maximum and passionate in working. In mobilizing, all activities and the creation of cooperation from all lines are unified, so that goals can be achieved smoothly and efficiently. ${ }^{12}$ The implementation task can largely be delegated. Implementation is to move, dynamism, control all organizational resources in an effort to achieve goals, and motivate the implementers to enable them to achieve maximum and passionate in working. In mobilizing, all activities and the creation of cooperation from all lines are unified, so that goals can be achieved smoothly and efficiently. The implementation task can be largely delegated. ${ }^{13}$

\section{d. Controlling}

Supervision is an effort to examine, compare or measure the implementation, as well as the results of the work achieved whether it is according to plan or not. ${ }^{14}$ Supervision needs to be done routinely by carrying out factual direct witnessing. In the process of supervision, supervisors must have mental courage without being reluctant to check and control work in the field. It is better to be reminded of the symptoms from the beginning, as a preventive measure, rather than to act and punish after something goes wrong. Control an absolute system must be run. A supervisor is required to be sporty, willing to accept the control of other parties. In essence, supervision is carried out with high spirits, openness, honesty, and a clean personality. ${ }^{15}$

The supervisory function is to: a) realize the efficiency and effectiveness of activities, b) realize the plans that have been prepared, c) prove whether an activity carried out in accordance with the plan and instructions or not, d) prevent the occurrence of various kinds of irregularities and deviations, e) fix all errors and weaknesses, and f) find a way out if there are mistakes in the hope of reconstruction in the future. ${ }^{16}$

\section{e. Evaluation}

Evaluation is a method of assessing and evaluating the success of communication activities that have been carried out, with the aim of improving or increasing the success that has been achieved previously. An evaluation is carried out to measure the success of the communication program. And evaluation is intended to review and control tasks, according to the norms and standards that have been outlined in the planning. Evaluation activities can be carried out starting from a predetermined goal, whether achieved or not, whether the level of achievement is high enough or still low. If the evaluation found errors, deficiencies, and deviations, corrections and revisions will be made immediately. The effectiveness of a communication program can only be known by evaluation. ${ }^{17}$

\section{Result and Discussion}

Islamic appearance has become the duty of every Muslim. This obligation is contained in the Qur'an Surah An-Nuur verse 31 and Al-Ahzaab verse 59. This verse is the

\footnotetext{
${ }^{12}$ Syahrizal Abbas, Manajemen Perguruan Tinggi (Jakarta: Prenada Media Group, 2009), p. 17.

${ }^{13}$ Al-Munawar dan Yusuf, Etika Manajemen, p. 12.

${ }^{14}$ Gouzali Saydan, Tanya Jawab Manajemen dan Kepemimpinan (Jakarta: Djambatan, 1993), p. 194.

15 Al-Munawar dan Yusuf, Etika Manajemen, p. 12.

${ }^{16}$ Ilyas, Manajemen Dakwah, p. 45-46.

${ }^{17}$ Ibid.
} 
basis of the Aceh government to implement Islamic-looking rules for every Muslim who has reached the position of Muslim. Long before Islamic-looking regulations were adopted, the Acehnese were quite concerned about appearance. So there is a fairly well-known Acehnese (narit maja) phrase spoken by the keut geutakot, geumalee keu peukayan. The meaning of this expression is that people are afraid of the strength of the armed forces and are reluctant to people who look good (neat, polite, and harmonious). Therefore, the Aceh government is responsible for carrying out the obligations of Allah to every Muslim and responds to the wishes of the Acehnese people to look Islamic in their daily lives by issuing a policy set forth in Qanun No. 11 of 2002 articles 13 and 23.

Policies that have been established in the Qanun should be a guideline in carrying out the rules. However, so far DSI as the executor of Qanun policy No. 11 of 2002 Article 13 and 23 faces difficulties and obstacles in carrying out the established rules. This is because the Qanun on Islamic dress code is not explained and detailed in the articles and verses. As stated by the Head of Da'wah Division of DSI Banda Aceh City, so far DSI has continued to move and run in the field of regulations issued, even though clear rules regarding Islamic appearance have not been stated in detail and orderly in detail. Responding to the issue of Islamic appearance rules in Aceh, DSI stipulates that at least the Islamic appearance meets four criteria. The four criteria referred to are clothing that is worn not narrow (body wrapping), not transparent (translucent), not made of unclean material, and not for arrogance when wearing it. ${ }^{18}$

Moving with the Islamic looking standard criteria as stipulated, DSI Banda Aceh City continues to carry out local government policies as stipulated in Qanun Number 11 Year 2002 Article 13 and Article 23. The implementation of Islamic performance in Banda Aceh City was taken seriously by DSI. Seriousness is reflected and stated through planned programming and design efforts. Planning regarding the implementation of Islamic-looking policies has been outlined in several programs and activities as a basis and reference for DSI work implementation. The following are a number of programs and activities that have been socialized and run by DSI as an effort to implement Islamic law, especially in the aspect of Islamic appearance to students in the city of Banda Aceh.

\subsection{Planning \\ a. Clothing Raids}

The clothing raid is one of the government's efforts to regulate how people look in Aceh. At the beginning of Qanun Number 11 Year 2002 Articles 13 and 23, a clothing raid was quite intense carried out by DSI located in the center of Banda Aceh City. The intensity of the clothing raid is intended as an effort to socialize Islamic dress policies. Socialization is considered important because Islamic dress policy is a new regulation issued by the Regional Government. In addition, clothing raids were carried out in order to bring order to the appearance issues which were considered and considered not in accordance with Islamic law and social norms, especially in the city of Banda Aceh. This is as stated by the Head of Da'wah Division of DSI in Banda Aceh City as follows.

In 2012 and 2013, DSI Banda Aceh City often conducted clothing raids. This year also became the initial stage for the socialization of Qanun. At that time, every Wednesday a clothing raid was conducted at three points. These three points are in front of the Mayor's Office, Simpang Lima, and Ulee Lheue. Initially, clothing raids were carried

${ }^{18}$ Ridwan Ibrahim, Kepala Bidang Dakwah Dinas Syariat Islam Kota Banda Aceh, interview 7 February 2017 
out because at that time there were still very many women in the city of Banda Aceh who were not yet wearing headscarves. ${ }^{19}$

The conduct of clothing raids leaves a distinct impression on students who have been caught in raids. Violators' feelings were mixed, like and dislike with this program. They feel like and accept it because it is appropriate for a Muslim to support the implementation of Islamic law in the area of Aceh which is nicknamed the City of the Veranda of Mecca. However, on the other hand, feelings of disappointment, fear, shame, resentment, and overreacting also haunt their feelings. This situation is felt especially by students who do not want to set their lifestyles and feel disappointed if implementing the rules cannot be a reference and role model for them as young people. As the informant said in response to the clothing raid program in Banda Aceh as follows.

I have been raided three times and am very upset. Upset arises because of rebuke. His name is difficult for adolescents to accept criticism and feel the most correct. At that time, everywhere became lazy because they had to deal with situations and the possibility of raids. When it comes out, we have our own business. But to that extent, not too angry and still like the Islamic Sharia. In fact, I am pro-Islamic Sharia even though I am still not sharia. After the raids, I was not interested too much care and care. Consider it the wind then and don't think too much. Let's just say this raid was a breeze. $^{20}$

\section{b. Safari Da'wah Minal Masjid Ilal Masjid}

Aceh is one of the largest Muslim populations in Indonesia. About 98 percent of the 4.4 million populations are Muslim. The city and village are filled with thousands of mosques. ${ }^{21}$ The existence of mosques everywhere makes Aceh the nickname of the Thousand Mosque. ${ }^{22}$ Most of the mosques are used as a container. The mosque functions as a center for the improvement of worship and for the empowerment of the people. Many activities are carried out in the mosque such as recitation, grand remembrance, religious events, and for community non-formal learning activities. And the mosque also functions to take shelter especially during times of conflict and the Tsunami disaster and also becomes a central place to meet. ${ }^{23}$ Having its strategic role and function, many institutions including DSI Banda Aceh City use the mosque as a place to socialize their programs.

Planning DSI Banda Aceh in an effort to uphold Islamic law, especially in the appearance of Islam through the activities of the Da'wah Minal Mosque Safari Ilal Masjid. Da'wah safari activities are routine activities carried out every Sunday night by urban preachers to all mosques in the city of Banda Aceh. Safari $D a^{\prime}$ wah has been going on since 2012 until now. As of 2017, the Banda Aceh City preaching safari team has visited a number of 97 mosques and meunasah. The main purpose of this activity is firstly, to provide enlightenment and debriefing to the community to prosper and revive mosques and meunasah

\footnotetext{
${ }^{19}$ Ridwan Ibrahim, Kepala Bidang Dakwah Dinas Syariat Islam Kota Banda Aceh, interview 12 February 2019

${ }^{20}$ Maulidar, Mahasiswa Universitas Syiah Kuala, interview 27 March 2017.

${ }^{21}$ Andreas Harsono, "Republik Indonesia Kilometer Nol," dalam Pantau (Desember 2003), p. 43.

${ }^{22}$ AP Archive, Prayers at Mosque which Survived Tsunami, diakses melalui www.youtube.com/watch?v=UsymBgB61A 18 July 2017, 11.49. See Wochit News, Thousands Pray at Indonesian Mosque That Survived, 10 Years After Tsunami, diakses melalui www.youtube.com/watch?v=wmYhWgpxcYk 18 July 2017, 11.56.

${ }^{23}$ Maimun Ibrahim, Pengurus Masjid Baitul Mukminin Desa Lamteh Ulee Kareng dan juga sebagai Dosen Mata Kuliah Manajemen Kemasjidan, wawancara tanggal 17 July 2017.
} 
in the city of Banda Aceh. And the second goal, to take religious responsibility through the provision of awareness rising on the people. ${ }^{24}$

Awareness propaganda material is delivered through tausiah. Dai urban ask people to participate in carrying out Islamic law. As for the targets of activities other than adults and adolescents. This activity was attended by students. And to make it easier for students to access activities, DSI carries out the Da'wah Safari to the campus mosque. The following snippet of the interview.

Da'wah Safari visits the UIN and Unsyiah mosques. Activities are often done. Even the

Dean of FDK UIN, Dr. Kusmawati Hatta, M.Pd, asked to follow up so that the DSI of

Banda Aceh City would collaborate by focusing on the issue of Da'wah. Even preaching is not only concentrated in the mosque, but can be done in Radio Assalam 107.9 FM. Then, for the study of propaganda material varied including discussion of Islamic clothing as socialized by the DSI so far. ${ }^{25}$

An illustration of the activities of the Da'wah Minal Safari Safari at the Ilal Masjid at the UIN Campus held on January 2, 2016 by DSI Banda Aceh City with the target being students in the male dormitory. ${ }^{26}$

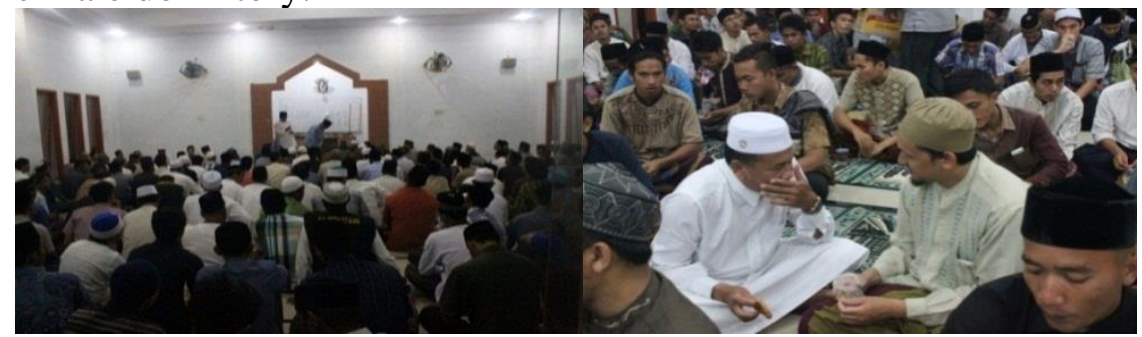

Figure 1. Minal Da'wah Safari Mosque Ilal Masjid at UIN Ar-Raniry

Source: DI Kota Banda Aceh, 2017.

Da'wah Safari activities managed by DSI Banda Aceh City are intended for the general public. Meanwhile, to better touch among the students, DSI specifically designed a program that is centered on the young generation who live far apart from their families. The program is known as the boarding house of $D a^{\prime} w a h$.

\section{c. Da'wah House Boarding}

DSI designed the House of $D a^{\prime}$ wah boarding program for overseas students. The aim is to support and accelerate the implementation of Islamic law. Overseas students are targeted by DSI because students who live in boarding houses are considered prone to violations of Sharia. This unrest is recognized by students and says that students tend to be free. The manifestation of freedom can be seen from the schedule of going home and going. They can go home and go without family control. Parents of overseas students cannot see their children's activities directly. ${ }^{27}$ Following are comments from the Head of Da'wah Division of DSI, Banda Aceh.

Based on observations and the fact that overseas students in the city of Banda Aceh still many violations of Sharia. Violations are caused by being away from parents. Thus, the self control system is not organized, except for those who live in the dormitory. The hostel is more binding and firm which makes them more awake. DSI has just

\footnotetext{
${ }^{24}$ Ridwan Ibrahim, Kepala Bidang Dakwah Dinas Syariat Islam Kota Banda Aceh, interview 12 February 2017.

${ }^{25}$ Ridwan Ibrahim, Kepala Bidang Dakwah Dinas Syariat Islam Kota Banda Aceh, interview 12 February 2017

${ }^{26}$ Documentation from Dinas Syariat Islam Kota Banda Aceh, 12 February 2017

${ }^{27}$ Nurjihan Yusni, Mahasiswa UIN Ar-Raniry, interview 10 May 2017.
} 
implemented the House of Da'wah for three villages from Kuta Alam District, namely Beurawe Village, Keuramat Village, and Lambaro Skep. ${ }^{28}$

\section{d. Da'wah Coffee Shop}

Drinking coffee has become a lifestyle for the people of Aceh. Rural and urban communities supplement their day with coffee. Aceh is identical with coffee lovers. This love can be seen from the mushrooming of coffee shops along the road, in villages and cities. There is even a coffee shop that is open 24 hours. Many and the life of a coffee shop in Aceh led to some artists and cultural figures in Aceh mentioning Aceh is the Land of a Thousand Coffee Shops. The site Metrotvnews.com even mentions Aceh as a Million Coffee Shop Country. The existence of a coffee shop is not just a place to eliminate thirst, but it serves as a restaurant, internet cafe, a place to watch football, a place to hang out, and as an information center. ${ }^{29}$ The many functions of the shop are the reason students love this place.

One of the targets of coffee shop Da'wah is students. Coffee shop became a hangout for students. In addition to the large number of trademarks with relatively cheap food and beverage price offers, they also facilitate their customers with Wi-Fi network services. The ease and speed of this facility certainly makes it easy for students to access their needs. Among the needs that make them feel at home for long sitting in the coffee shop with the reason to get lecture assignments. Responding to the coffee shop hangout phenomenon, DSI Banda Aceh City since 2013 until now, continues to intensely carry out his Da'wah by picking up the ball. The following is a review of its activities.

DSI visited Coffee Shops that were crowded with visitors such as Cut Nun, Helsinki, Taufik, and Solong. The technical implementation is coordinated directly by DSI. During the visit, the Coffee Shops propaganda team brought complete equipment, ranging from lecturers, sound systems, and presenting most of the urban preachers as supporters in enlivening activities. Da'wah Coffee Shops attracts the attention of visitors, in addition to the funny lecturer, the contents of the material are varied. Interestingly, for food and drinks visitors will be borne by the committee (DSI). The activity is carried out twice a month after the Asr prayer. The choice of time is intended so that after listening to the lecture, stall visitors, including students, will go directly to the mosque to perform Maghrib prayer in congregation. ${ }^{30}$
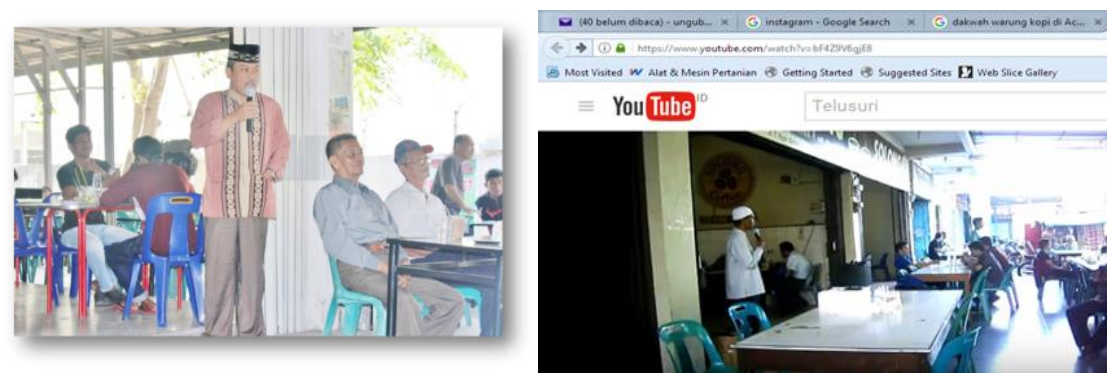

Figure 2. Coffee shops Da'wah Activities

Source: DSI Banda Aceh City and YouTube channel, 2017.

\footnotetext{
${ }^{28}$ Ridwan Ibrahim, Kepala Bidang Dakwah Dinas Syariat Islam Kota Banda Aceh, interview 12 February 2017.

${ }^{29}$ Travel.kompas.com, Aceh Negeri Seribu Warung Kopi. Diakses pada tanggal 23 Juli 2017, pukul 03.44. Lihat juga abulyatama.ac.id, Aceh juga dikenal dengan Negeri Seribu Warung Kopi. Accessed July 23, 2017

${ }^{30}$ Ridwan Ibrahim, Kepala Bidang Dakwah Dinas Syariat Islam Kota Banda Aceh, interview on February 2, 2017.
} 
DSI Banda Aceh City hopes that the Coffee shops missionary activity can be one of the solutions in disseminating local government policies. In addition, this program is a form of government concern for the problems faced by the people of Aceh. The issue of appearance becomes phenomenal because today much adolescent dress does not comply with the standards offered. Although the material of preaching in Coffee shops missionary activities does not merely discuss the way of Islamic appearance. However, the spirit of $D a^{\prime} w a h$ continues to be done anytime and anywhere. Therefore, DSI Banda Aceh City designed a program that was intended for all groups, including students. The program is known as Public Da'wah.

\section{e. Public Da'wah}

Public Da'wah is a sympathetic propaganda activity carried out by urban preachers in locations that are crowded with visitors. Technical activities, he came to the public area to preach. The intended public areas such as soccer fields, shopping centers, beach areas, tourist attractions, and campus environments. The form of public preaching activities tends to pick up the ball. Dai meets face to face with targets in public spaces. The DSI team goes directly to the location in a personal approach to provide problem solving or advice to the community and certain communities. In addition, he also went around while preaching by using the Islamic Sharia operational car around Banda Aceh. The following is an interview excerpt about public propaganda.

Public Da'wah is done in crowded places such as Ulee Lheue beach, campus grounds, and market centers. Public Da'wah is carried out using a microphone and preaching on the Islamic Sharia operational car. DSI try as much as possible so as not to burden the target. Dai urban tried to apply and follow the pattern of the propaganda of the Prophet, where he came directly to mad'u by applying sympathetic propaganda. ${ }^{31}$

Public $D a^{\prime}$ wah is carried out collectively. Dai is not on duty alone. They formed a work team to be able to reach and capture a lot of honey at the same time. Dai went to the audience and delivered his message in the simplest and most flexible way possible. The theme of Da'wah is situational and on the spot. At the same time, he discussed various themes according to the needs and desires of the audience. In the same time he could have discussed the problems of buying and selling, worship, aqeedah, morals, ukhuwah, promiscuity, and also clothing. The following is the explanation by the Head of Da'wah Division of DSI in Banda Aceh. Public Da'wah is a routine monthly activity carried out in a number of areas of Banda Aceh. The determination of the location of activities is based on reports from the local community. Technical activities are carried out by way of going around the city first and stopping at the destination of Da'wah. As was done on May 13, 2017, dozens of urban DSI together with Muhtasib villages in the Syiah Kuala and WH districts of Banda Aceh City, Saturday afternoon did public preaching on the beach of Alue Naga village.

\section{f. $D a^{\prime}$ wah Media}

One of the successes of Da'wah is the accuracy in using the media. That is, propaganda does not succeed if it is unable to function and maximize the effective use of media. This important media role is used by DSI Banda Aceh City in carrying out its Da'wah activities. DSI created a program called Da'wah Media. In general, the DSI of Banda Aceh has been functioning three forms of media in disseminating Islamic symbols including publicizing

\footnotetext{
${ }^{31}$ Ridwan Ibrahim, Kepala Bidang Dakwah Dinas Syariat Islam Kota Banda Aceh interview on February 2, 2017.
} 
government policies on the application of Islamic dress in Aceh. The forms of media used are mass media, social media, and also mass media.

Mass media is one of the effective media to reach broad, fast, and diverse targets. A policy will be quickly known by many people, if broadcast and reported through this media. DSI Banda Aceh in socializing the application of Qanun through its programs also uses local mass media. Mass media used such as local TV, local radio, and local newspapers. Aceh TV is one of the audiovisual electronic mass media used by DSI Banda Aceh City in publicizing its activities, including in socializing the application of Islamic appearance. Besides that, Ridwan Ibrahim as the Head of Da'wah Division of DSI said that especially in the month of Ramadan for 29 or 30 days, DSI Banda Aceh City filled the program in one of the Aceh TV programs. ${ }^{32}$ The following is the documentation of the process of recording activities on Aceh TV.
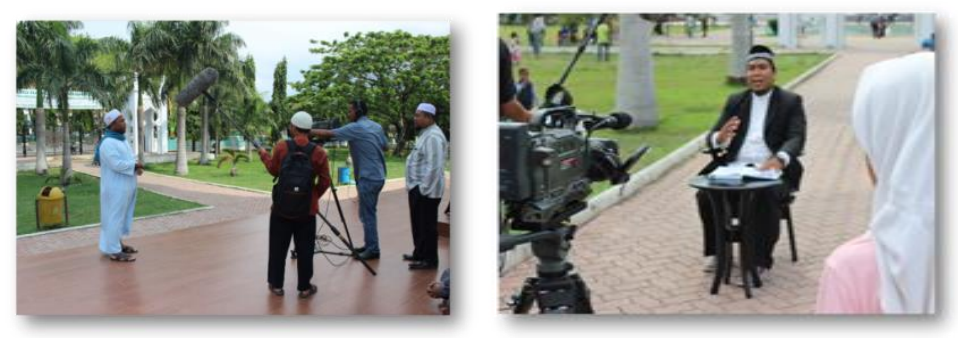

Figure 3. Da'wah Media in Aceh TV

Source: DSI Banda Aceh City, 2017.

In addition to Aceh TV, DSI Kota Banda Aceh also uses radio as a means to socialize the application of Qanun. There are a number of local radio stations that are active on the air in Banda Aceh. Among them Baiturrahman FM Radio 98.5 MHz., Pro 1 RRI Banda Aceh FM 97.7 MHz., Pro 2 RRI Banda Aceh FM 88.6 MHz., Toss FM 99.3 MHz., Rumoh FM FMI PMI 107 MHz., Meugah FM 95.3 MHz., Bingkara FM 89.4 MHz., Serambi FM 90.2 MHz., Djati FM 103.6 MHz., Flamboyant FM 105.2 MHz., Kontiki FM 101.2 MHz., Oz FM 102.8 MHz., Radio Tri FM 94.5 MHz., Radio Assalam FM 107.9 MHz., Seulaweut FM 91.0 MHz., And Antero FM $102 \mathrm{MHz}$. Among the many local radios in the city of Banda Aceh, DSI has collaborated with Radio RRI Pro 1 Banda Aceh, Radio Djati $103.6 \mathrm{MHz}$, and Seulaweut FM 91.0 MHz to fill in a continuous program on one of the radio programs.

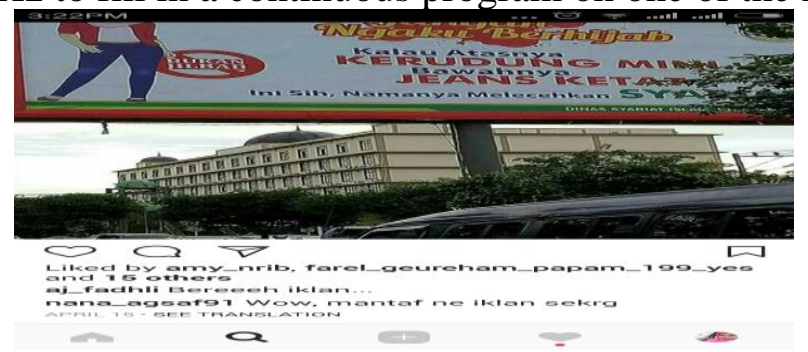

Figure 4. Da'wah through Billboards

Source: DSI Banda Aceh City, 2017.

In addition to mass media and mass media, the Banda Aceh Syariat Islam Office also uses social media to publicize its activities. Activities are socialized using social media Facebook, Instagram and YouTube.

32 Ridwan Ibrahim, Kepala Bidang Dakwah Dinas Syariat Islam Kota Banda Aceh, interview on February 2, 2017. 


\section{g. Recitation of Tahsin Wednesday}

Wednesday Tahsin study is a routine activity carried out by urban daiyah DSI Banda Aceh. This activity is carried out in mosques and prayer rooms attended by women. So far, the majority of activities in Wednesday midwifery study have been attended by mothers, although this routine activity has the opportunity to join students. Based on information on social media, the Wednesday prayer session was not crowded. Daiyah commented via the Instagram account @ fitriani7785, saying "Still like last week, there is not much interest, loss ... loss ..." The following Instagram screenshot is intended.

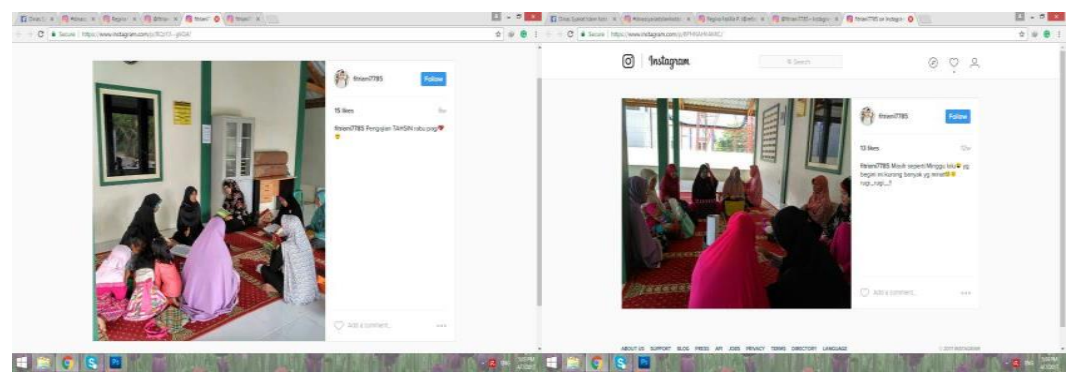

Figure 5. DSI Wednesday Study Meeting

Source: Instagram account @ fitriani7785, 2017.

\section{Conclusion}

The most girls' appearance in Banda Aceh still does not apply the rules as socialized by the Islamic Sharia Agency. The mismatch between the applications in appearance with the rules for Islamic appearance is certainly not only seen as a single violation, but more understood as a whole reality, as a social reality of communication. The reality of life is very dynamic and constantly changing. Changes in the way students look must be balanced with the rules in force. Offsetting can be circumvented through communication management.

DSI requires accurate communication management to be able to balance changes so that the application of Islamic appearance among students is in accordance with Islamic law. The balance between the rules and the application can be done through optimal improvement in the elements of communication management. Planning, organizing, implementing, controlling, and evaluating ideally should be carried out in a focused and planned manner by DSI Banda Aceh as the maker and implementer of policies so that the application of Islamic performance in accordance with Sharia can be realized among students.

Communication management of DSI Banda Aceh City in implementing Islamic appearance has not been maximized. Of the seven activities carried out only clothing raid activities that are more focused in controlling the appearance of the people of Aceh. The activity was carried out by raiding people who did not look in accordance with the description of clothing as published on the banner. Invitations to look Islamic so far have been inserted in traditional $D a^{\prime}$ wah conducted in the mosque. The organizing concept carried out by DSI is played by urban preachers. Even though those who were sent could not become student idols. 


\section{References}

Adisasmita, Rahardjo. (2006). Pembangunan Pedesaan dan Perkotaan. Yogyakarta: Graha Ilmu.

Badan Pusat Statistik. (2018). Kecamatan Hamparan Perak Dalam Angka 2017. Deli Serdang: BPS.

Bintaro, R. (1989). Dalam Interaksi Desa - Kota dan Permasalahannya. Jakarta: Ghalia Indonesia.

Batubara, Maria Ulfa. (2019). Islamic Communication Pattern of Judges in Dealing Conflict of Muslim Families in the Religious Court Medan. Budapest International Research and Critics Institute (BIRCI-Journal).p.373-386.

Cangara, Haafied, (2013). Perencanaan dan Strategi Komunikasi, Jakarta: Rajagrafindo Persada.

Dilla,Sumadi. (2007). Komunikasi Pembangunan Pendekatan Terpadu, Bandung: Simbiosa.

Basrowi dan Suwandi. (2008). Memahami Penelitian Kualitatif. Jakarta: Rineka Cipta.

Kartohadikoesoemo, Soetardjo. (1984). Desa. Yogyakarta: PN Balai Pustaka.

Miles,M.B, Huberman,A.M, and Saldana, J. (2014).Qualitative Data Analysis, A Methods Sourcebook Edition 3. USA: Sage Publications.

O'Sullivan, Arthur. (2003). Urban Economics, Fifth Edition. NewYork: McGraw-Hill.

Robbin, Stephen P., (2002). Prinsip-prinsip Perilaku Komunikasi Organisasi Jakarta: Erlangga.

Sutoro E, et.al. (2014). Desa Membangun Indonesia. Yogyakarta: Forum Pengembangan Pembaharuan Desa (FPPD).

Undang-Undang Nomor 6 Tahun (2014) Tentang Desa

Undang- Peraturan Pemerintah Nomor 72 Tahun (2005) Tentang Desa Pasal 1

Pasal 14 Peraturan Pemerintah No.72 Tahun (2005) 